\title{
Understanding marketing innovativeness in Asia: a research agenda
}

\author{
Ibrahim Abosag ${ }^{1}$ David Ross Brennan ${ }^{2}$
}

(C) Macmillan Publishers Ltd 2017

\begin{abstract}
Marketing innovativeness has been credited for improvements in general quality of life, consumer experience, and firms' and brands' performance. However, much of the knowledge and research on marketing innovativeness has developed from studies in Western countries, particularly the USA and Europe, with little understanding of marketing innovativeness in Asia. In this paper, we critically examine existing literature with aim of developing a better understanding of marketing innovativeness in Asia. We discuss theoretical and methodological considerations of which researchers need to be aware when they pursue research on Asian countries.
\end{abstract}

Keywords Marketing · Innovation · Brand · Organisation · Asia

\section{Introduction}

Innovation is the process whereby new products, services and ideas are developed and brought to market with the aim of enhancing and strengthening profitability, which is reliant on satisfying consumers more efficiently and better than competitors. Understanding consumers and competition has always been the focus of marketing, and hence marketing has been a good guide towards more effective innovation to satisfy consumers, reduce competition and ultimately enable firms to achieve profitability. In a much-cited comment, Drucker (1954, p. 37) stated "business enterprise has two-and only two-functions: marketing and innovation". Given this link between innovation and marketing, we use the term marketing innovativeness throughout this paper.

Ibrahim Abosag

ibrahim.abosag@soas.ac.uk

1 SOAS, University of London, London, UK

2 University of Hertfordshire, Hatfield, Hertfordshire, UK 
Growing attention is being paid to marketing innovativeness as a cornerstone in a firm's successful performance and as a way of sustaining competitive advantage in foreign markets. Marketing innovativeness encompasses various types of activities, the most obvious being product innovativeness (e.g. Han et al. 1998; Hurley and Hult 1998; Kirca et al. 2005; Theoharakis and Hooley 2008), service innovativeness (e.g. Garcia and Calantone 2002; Kleijnen et al. 2005; Zolfagharian and Paswan 2009), consumer innovativeness (e.g. Goldsmith et al. 1998; Im et al. 2003; Im et al. 2007; Truong 2013), brand innovativeness (e.g. Alam and Perry 2002; Boisvert and Ashill 2011), and supplier innovativeness (Choi and Krause 2006; Inemek and Matthyssens 2013). Other types of innovativeness related to marketing include organisational (e.g. Tuominen et al. 2004; Yu et al. 2013) and technology innovativeness (e.g. Hirunyawipada and Paswan 2006). Innovativeness refers to "a firm's capacity to engage in innovation: that is, introduction of new processes, products, or ideas" (Hult et al. 2004, p. 429). Such a capacity is an essential factor influencing firm performance (e.g. Hurley and Hult 1998; Cooper 2000; Hult et al. 2004; Boso et al. 2013). While some studies have examined the antecedents of marketing innovativeness, mainly market and learning orientations (e.g. Deshpandé and Farley 2004; Hult et al. 2004) and consequences such as firm performance (e.g. Sandvik and Sandvik 2003; Theoharakis and Hooley 2008), the identified antecedents and consequences of marketing innovativeness have been limited to a few constructs. Furthermore, although the concept of marketing innovativeness is universally applicable, most studies in this area of research have been conducted in Western countries (e.g. Tellis et al. 2003; Stremersch and Tellis 2004), and thereby lack cross-cultural examination (e.g. Steenkamp et al. 1999; Tellis et al. 2009). Thus, there is a need to expand research geographically in the area of marketing innovativeness to take into account international complexity.

Despite the widespread focus on the internationalisation of businesses and the substantial investments that governments and businesses are making, research in international marketing innovativeness is scarce, especially relating to Asian countries. The few available studies in this area are largely focused on cross-cultural consumer innovativeness (e.g. Steenkamp et al. 1999; Yalcinkaya 2008; Tellis et al. 2009; Boso et al. 2013; Kumar 2014). Other types of marketing innovativeness are seriously under-researched. In addition, only a few studies look at emerging markets in this area (e.g. Steenkamp and Burgess 2002; Boso et al. 2012; Yu et al. 2013). While many studies have found that marketing and innovation lead to better overall performance, little is known about how the antecedents of marketing innovativeness contribute to different aspects of performance as well as other important outcomes; and, moreover, about how the antecedents of marketing innovativeness operate under varying external conditions.

With the aim of providing a structure for thinking about innovation and marketing, this paper focuses on three key elements of marketing innovativeness that facilitate understanding of the current challenges and opportunities that exist in Asia: product and brand innovativeness, customer responsiveness to innovation, and firm and market innovativeness. In addition, we highlight important gaps in this area of research, and provide guidance for future study. 


\section{Product/brand innovativeness}

Product innovativeness is defined by Sethi et al. (2001) as the extent to which a new product delivers meaningfully unique benefits; it can be a primary determinant of the success of a new product through product differentiation in comparison with competing products. Prior studies on product innovativeness have addressed both firm and customer perspectives (Daneels and Kleinschmidt 2001; Garcia and Calantone 2002). Brand innovativeness is defined as the perceived newness and novelty that strengthen and enhance brand loyalty and commitment (e.g. Sethi et al. 2001; Daneels and Kleinschmidt 2001; Lee and O'Connor 2003; Eisingerich and Rubera 2010). Both brand and product innovativeness are defined by perceived newness, novelty of features, uniqueness of functionality, and benefits (Lee and O’Connor 2003).

Brand innovativeness, when engaged towards creating international corporate reputation, concerns brand image (Keller and Aaker 1998); brands that are perceived as innovative have been found to impact positively on firm credibility (Gurhan-Canli and Batra 2004), implying a higher level of expertise, which in turn makes the brand more attractive and trustworthy (Keller and Aaker 1998). Recent studies show that product innovativeness enhances customers' perception of brand innovativeness (e.g. Boisvert and Ashill 2011; Schreir et al. 2012; Rubera and Kirca 2012), and that there is a spill-over effect from 'flagship' products on brand innovativeness (Hubert et al. 2017).

The literature on brand innovativeness in Asia is characterised by two major issues. Firstly, despite numerous studies of brands and branding in Asian countries (e.g. Cayla and Eckhardt 2007), little is known about the processes that determine the perception of innovativeness of Asian brands. Understanding such perceptions within Asia is as important as perception of Asian brands innovativeness in the rest of the world, and requires more attention. Recent studies (e.g. Cayla and Eckhardt 2008; O'Cass and Siahtiri 2013) have started to bring insights into inter-country brand innovativeness. However, such efforts are still fragmentary, and lack theoretical focus. Secondly, studies from within and outside Asia tend to focus on the three big economies of Japan, China and South Korea; i.e., well-performing second-tier brands from less-developed countries also require more attention. Moreover, few studies have compared Asian consumers' perception of brands from different Asian perspectives (e.g. Shukla 2011; Shukla et al. 2015), calling again for more comparative studies to seek insight on Asian brand innovativeness and its effect on the internationalisation of such brands.

\section{Customer responsiveness to innovation (customer innovativeness)}

Customer innovativeness concerns the customer's tendency toward novelty-seeking and risk-taking behaviour (Hirschman 1980). Early literature focused on the propensity to adopt new products earlier than the global customer average (Rogers and Shoemaker 1971). Time of adoption as an indicator of customer innovativeness 
divides customers into innovators and non-innovators (Rogers and Shoemaker 1971). In recent years, customer innovativeness has been assessed at an abstract level, including the use of personality measures (e.g. Goldsmith et al. 1995; Hirunyawipada and Paswan 2006) often based on multiple motivation dimensions, including hedonic, functional, social and cognitive (Tian et al. 2001).

Prior studies have highlighted varieties of customer innovativeness across countries (Tellis et al. 2009), the way in which national culture influences customer innovativeness (Steenkamp et al. 1999), and cultural effects on attitudes toward innovation (Truong 2013). The literature suggests that highly-innovative customers have a higher tendency to capture value, seek novelty and accept risk than other consumers (Roehrich 2004; Rogers 2003). However, more recent studies have provided evidence that novelty-seeking (Tse and Crotts 2005), value-capturing (Watchravesringkan et al. 2008), and risk-taking behaviour (Tellis et al. 2009) vary significantly, according to different cultural values and norms.

It is notable that while the number of studies on customer innovativeness amongst Asian consumers has been growing, studies that compare similarities and differences in customer innovativeness among Asian countries have been limited, as have studies comparing Asian with Western consumers.

\section{Firm and market innovativeness}

The ultimate aim of marketing innovativeness is to enhance and strengthen firm performance though greater customer satisfaction, engagement, and participation in value co-creation activities, as well as achieving a better competitive position in the marketplace. A key factor in a firm's business performance is its innovation capacity (e.g. Hurley and Hult 1998; Henard and Szymanski 2001), and the ability to develop new products/services and/or markets is seen as critical for survival in increasingly competitive markets (Wang and Ahmed 2007). Firm innovativeness is essentially a marketplace-based advantage, obtained through the development of new products and markets. Thus, firm innovative capability is the ability to efficiently align resources and capabilities with products and services in the marketplace (Mota and de Castro 2004). The level of firm innovativeness largely determines a firm's capabilities to bring new products/services to the marketplace, and enables it to achieve greater competitive advantage (e.g. Tripsas 1997; Lazonick and Prencipe 2005; Rubera and Kirca 2012). The more a firm can absorb and share resources, the more likely it is to be innovative through the creation of new knowledge and understanding that translates into more satisfying products and services for customers (Kunza et al. 2011).

Most studies on firm and market innovativeness have focused on the context of Western or international firms (e.g. Wu 2008; Wang and Chung 2013; Hwang and Hyun 2016). What literature exists on the innovativeness of Asian firms is characterised by a variety of gaps. First, the literature on Asian firms' innovativeness is fragmented and often spread over many areas such as strategic management, international business and international marketing, with little theoretical or empirical integration, which limits our understanding of the antecedents and 
outcomes of Asian firms' innovativeness. Thus, as more and more Asian firms expand internationally, the need to understand how specific Asian cultural contexts affect firms' innovativeness becomes more important; studies are needed to bring seemingly distinct but naturally related research areas into clearer focus. Second, in recent years firms like Alibaba, Shanghai Tang, Mahindra, Amorepacific, and Baidu have achieved substantial value growth-but the literature remains unable to explain how firm innovativeness translates into determining firms' value in the market. The impact of innovativeness on firm performance in Asia has been investigated (e.g. Qian and Li 2003; Zhou et al. 2005), but findings from these studies are not cumulative, so that a theory-driven model that integrates these findings to examine how firm innovativeness affects firm value is absent. Third, there are inconsistent findings from studies focused on Western firms concerning the influence of firm innovativeness (e.g. Walker 2004; Wolfe 1994).

The dominant view is that firm innovativeness positively affects firm performance (e.g. Srinivisan et al. 2009; Tellis et al. 2009). However, findings from other studies have shown either negative or insignificant effects on performance from firm innovativeness (e.g. Baum et al. 2000; Mengüç and Auh 2006). The findings from studies focused on Asian firms have largely supported the view that firm innovativeness positively affects firm performance (e.g. Zhou et al. 2005), but further studies would be useful to examine such relationships in more detail.

\section{Considerations for future research}

\section{Theoretical considerations}

Following on from the above discussion on aspects of marketing innovativeness that can provide researchers with insights, this section addresses some theoretical challenges that researchers need to consider. Contributions to theory on marketing innovativeness have been largely generated from Western countries. In recent decades, Asian contributions are growing, with some distinctive inputs. Traditionally, Asian firms have imitated firms from highly-developed Western economies (Hobday 1995), using a variety of strategies including joint ventures, subcontracting, and strategic alliances, through which the Asian firms have developed knowledge and expertise. This approach has been effective in enhancing the competitiveness of some developing economies. However, only a few leading countries such as China and Korea have reached the stage where knowledge-based innovation has started to grow rapidly. Unfortunately, despite rapid change in Asia, theory directed towards Asian firms' marketing innovativeness is still marginal and insufficiently focused on knowledge-intensive goods and services. One productive focus for researchers might therefore be on knowledge-intensive goods and services from developing Asian countries, which are currently largely assemblers of goods, and do not capture much value from any role in manufacturing.

In recent years, Asian firms have expanded significantly. While some have acquired existing Western brands and operate through them, a number of Asian brands have entered new markets (mainly in Europe and North America) using their 
country of origin identity. This provides another research opportunity, to ascertain how Asian brands engage non-Asian consumers, which might address two questions in particular: What is distinctive about Asian brand innovativeness compared with non-Asian? What are the processes that determine the perception of innovativeness of Asian brands within and outside Asia? The very concepts of 'novelty' and 'newness' vary across different cultures (e.g. Tellis et al. 2009; Shukla et al. 2015) and attitudes to product and brand innovativeness are shaped to large extent by cultural (Truong 2013) as well as economic factors. A comparative approach that involves two types of comparison might address this issue. Firstly, investigation of similarities and differences within Asian countries may provide insights into the degree to which certain activities are unique to certain countries and others shared across countries; secondly, comparison with product and brand innovativeness in Western countries should indicate similarities and differences between Asian and Western brands.

Despite several studies of Western consumers' responsiveness to marketing innovativeness (e.g. Roehrich 2004; Im et al. 2007), there are few studies into Western consumers' responsiveness to Asian brands. Though consumer innovativeness in the West has been addressed in relation to novelty-seeking and risktaking behaviour (e.g. Tse and Crotts 2005), more studies with an Asian focus would be welcome. Two issues seem appropriate foci of attention: Western consumers' perceptions and attitudes towards Asian brands, especially those from developing Asian countries; and Asian consumers' admiration for and aspiration to Western brands, alongside Asian consumer responsiveness to brands from developing Asian countries.

Recent literature has often focused on online marketing innovativeness, through which brands are increasingly engaging with consumers (e.g. Aldás-Manzano et al. 2009). Internet technologies have massively changed the landscape of brand innovativeness, such as in brand-sponsored social-networking sites that provide opportunities for both brands and consumers (e.g. Hennig-Thurau et al. 2004; Sponder 2012; Beukeboom et al. 2015). These venues enable consumers to influence brands and to respond quickly to brand innovativeness in ways that create value for brands and consumers alike (e.g. Hanna et al. 2011). Online brand innovativeness is growing in Asian countries just as in other parts of the world, but has been hindered by number of factors, such as a lack of English proficiency in some consumers; the difficulties faced by global brands in some Asian countries due to restrictions on global social-networking sites like Facebook; and the lack of takeup by global brands of consumer-value co-creation activities normally found in the West.

Consumer responsiveness in Asia, not just to global but also to Asian brands, with attention moreover to the online dimension, could offer fruitful insights. Consumer responsiveness is underpinned by cognitive and emotional motives. Thus, we would hope that researchers might seek to map out the motives that determine the nature of consumer innovativeness within Asia, especially from developing countries including China, Korea and Malaysia. 


\section{Methodological considerations}

The broad topic area itself, marketing innovativeness, is a combination of two areas, marketing and innovation, where novelty is, or at least should be, prized. This sense of novelty could be carried over into methodology in research design and context. A number of specific ideas suggest themselves: avoiding too much straightforward testing of theories derived from the Western literature in the Asian context; making explicit reference to Eastern cultural contexts and concepts; considering methodological pluralism; and considering the practical implications of the research at the design, not just the writing-up, stage.

While there can be merit in taking what is regarded as 'established theory' and testing it in a new context, there is also scope for more theory-testing research. A problem can arise, however, with theories largely based on Western studies and communicated via Western journals, when the point of the research is to explore their applicability in the context of Asian nations. The unfortunate implication can be a dominant/subordinate relationship between Western and Eastern research; theories are empirically developed in the West and tested in the East- that Asian countries are regarded as useful test-beds in which to check the universality of Western models. This tends to reinforce a Western, and particularly North American, hegemony in business research (Jaya 2001).

A very natural means of emancipating Asian research into marketing innovativeness from Western research is to make more extensive use of uniquely Asian cultural contexts and concepts. Thus far, most published business research involving Asian cultural constructs has focused on Chinese culture and concepts such as guanxi, xinren and mianzi (Fan 2002; Fang 2006; Faure and Fang 2008; Wilson and Brennan 2010). This focus makes sense given the global economic significance of China, and of wider Chinese culture among the extensive Chinese diaspora. There have more recently been efforts to include other non-Western cultural concepts into the business, management and marketing literature; notably, Arab concepts such as wasta and et-Moone have received growing attention (Hutchings and Weir 2006; Abosag and Naudé 2014; Abosag and Lee 2013). However, from a research-design perspective, the emphasis remains largely on identifying how Western theories need to be adapted to incorporate insights into non-Western cultural concepts. Perhaps a different question should be asked: is there a unique way of looking at marketing innovativeness that is fundamentally different because of the cultural context and the cultural concepts used by the observer? Is it enough to add Eastern cultural concepts into Western models, or does the adoption of an Eastern perspective mean that Western models are fundamentally inapplicable because of presuppositions they make about cultural understanding? These questions simultaneously raise issues concerning methodology and research design, and suggest potential research topics.

Opening up a new area of research, i.e. marketing innovativeness in Asia, provides the opportunity for researchers to consider a wider range of methodological options than perhaps they normally would. There are many arguments in favour of methodological pluralism in the business and management field generally, and they are all the stronger for being deployed in an emerging field of research. 
Pluralism can be applied at three levels: theoretical, methodological and methodical (Midgley et al. 2017). All three levels are relevant to the field of marketing innovativeness in Asia. The previous two paragraphs can be seen as a plea for theoretical pluralism: urging researchers to seek new theoretical approaches rather than to replicate Western approaches, and suggesting that one source of such approaches lies in treating Asian cultural concepts as foundational components of research design. Methodological pluralism is the theory and practice of drawing upon methods from two or more different paradigmatic sources and using them together within a single study. Using different methods within a single study provides insights that a mono-method approach cannot, creating the possibility of seeing the research problem from a new and creative angle (Midgley et al. 2017).

Discussion of pluralist approaches leads naturally into a discussion of the relevance of academic research to the practical world, which may be the world of business-people (managerial implications), public administrators (policy implications), or others. The relevance of business and management research to practical matters (particularly regarding criticisms of low relevance) has long been a matter of concern (Zinkhan 2006; Brennan et al. 2014; Baines et al. 2009; Jaworski 2011; Dawson 1971). One reason for the perceived irrelevance, it is argued, is that the most commonly used academic research methods are de-contextualised; they neither attempt nor succeed in providing insight into the complex realities of realworld experience, but concentrate on establishing formal statistical relationships between highly abstract constructs-whereas potential users of research, such as managers and policy-makers, operate in context-specific circumstances and with concrete ideas and concepts, rather than complex, abstract constructs.

A final consideration for researchers, therefore, is how to make their study genuinely relevant to potential users, such as managers and policy-makers. We hope we have already provided some clues: we should not simply test Western theories in an Asian context; we should seek uniquely Asian theories built on Asian cultural contexts and concepts; and we should consider using pluralistic approaches. However, this is only a rough sketch of a way forward which needs to be developed creatively and uniquely in any new-research design.

\section{Contributions to marketing and innovation in Asia}

The first paper in this special issue sits squarely within the product/brand innovativeness theme discussed above. Cho et al. (2017) argue that new-product development is critically important in achieving international marketing success. A key question therefore arises concerning the antecedents to successful new-product development, which is a topic that has been extensively studied in the domestic context, but relatively little in the context of internationalisation. The key research questions addressed are whether the degree of international orientation and crossfunctional integration a firm achieves are important factors influencing international new-product development success for Asian firms. International orientation is conceptualised as 'a global mindset', a strong managerial focus on the development of resources and capabilities that facilitate success in international markets. Cross- 
functional integration refers to the extent to which coordination is achieved between all functions contributing to the new-product development process, with coordination between $R \& D$ and marketing being particularly important. The empirical approach adopted was to administer an email questionnaire to 1000 Korean manufacturing firms, which included a good balance between consumer-product and industrial-product companies. The results show that cross-functional integration acts as a significant moderator in the relationship between international orientation and international market performance, but not in the relationship between international orientation and financial performance. The authors conclude that integration between functions is particularly important for Asian SMEs pursuing internationalisation.

In the second paper, the innovative activity that Hong and Kim (2017) investigate is the use of corporate social responsibility as a tool in the market for talented employees. As emerging-market economies mature, so emerging-market multinational enterprises (EMNEs) are becoming increasingly influential globally. As EMNEs broaden their geographical scope, so they need to employ more and more local workers in the countries where they operate. However, developed-country multinational enterprises are usually already well established in these countries, so that EMNEs have to engage in a competitive battle to recruit a high-quality local workforce. An employing organisation's country of origin makes a difference to the job-pursuit intentions of members of local labour markets; for example, all other things being equal, many potential employees would rather work for an American than a Chinese company. By studying the job-pursuit intentions of 179 Korean job seekers, Hong and Kim (2017) establish that the strategic use of CSR activities can have a positive influence on the ability of EMNEs to attract local workers. So, for example, Chinese multinationals, when trying to compete with American multinationals for talented workers in a third country (such as Korea), can improve their chances of success by engaging in CSR activities that are perceived favourably by members of the local labour force.

The third paper looks at customer innovativeness in a Chinese empirical context. In two empirical studies with, respectively, 171 and 90 young Chinese adults, Martin and Tao-Peng (2017) considers the moral traits that are associated with two different celebrities, the extent to which the respondents identify with those celebrities, and how these factors might influence consumers' purchase intention. Celebrity endorsement is an extremely widely-used marketing tool. The research context for the empirical study is the market for online gaming products. The paper introduces us to two well-known celebrities, one Western (the global pop star of Canadian origin, Justin Bieber) and the other Eastern (the global online gaming star of Korean origin, Lee Sang-Hyeok, who performs under the pseudonym 'Faker'). The results show that the impact of celebrity endorser moral traits on purchase intention among respondents of Chinese origin is context-dependent, so that in some cases the moral traits of the celebrity endorser matter, but not in others. In particular, cultural conditioning can affect the extent to which consumers will tolerate ethically dubious behaviour by the celebrity. When evaluating celebrity misbehaviour, Chinese consumers seem to be more heavily influenced by social norms than Western consumers. It is suggested that a company intending to use Western 
celebrity endorsement in an Asian market needs to research the perception of the celebrity's life-style among Asian consumers.

\section{References}

Abosag, Ibrahim, and Joong-Woo Lee. 2013. The formation of trust and commitment in business relationships in the Middle East: Understanding Et-Moone relationships. International Business Review 22 (3): 602-614.

Abosag, Ibrahim, and Peter Naudé. 2014. Development of special forms of B2B relationships: Examining the role of interpersonal liking in developing Guanxi and Et-Moone relationships. Industrial Marketing Management 43 (6): 887-896.

Alam, Ian, and Chad Perry. 2002. A customer-oriented new service development process. Journal of Service Marketing 16 (6): 515-534.

Aldás-Manzano, Joaquín, Carlos Lassala-Navarré, Carla Ruiz-Mafé, and Silvia Sanz-Blas. 2009. The role of consumer innovativeness and perceived risk in online banking usage. International Journal of Bank Marketing 27 (1): 53-75.

Baines, Paul R., Ross Brennan, Mark Gill, and Roger Mortimore. 2009. Examining the academic/commercial divide in marketing research. European Journal of Marketing 43 (11/12): 1289-1299.

Baum, Joel A.C., Tony Calabrese, and Brian S. Silverman. 2000. Don't go it alone: Alliance network composition and startups' performance in Canadian biotechnology. Strategic Management Journal 21 (3): 267-294.

Beukeboom, Camiel J., Peter Kerkhof, and Metten de Vries. 2015. Does a virtual like cause actual liking? How following a brand's Facebook updates enhances brand evaluations and purchase intention. Journal of Interactive Marketing 32: 26-36.

Boisvert, Jean, and Nick Ashill. 2011. How brand innovativeness and quality impact attitude toward new service line extensions: the moderating role of consumer involvement. Journal of Services Marketing 25 (7): 517-527.

Boso, Nathaniel, John Cadogan, and Vicky Story. 2012. Entrepreneurial orientation and market orientation as drivers of product innovation success: A study of exporters from a developing economy. International Small Business Journal 12: 1-25.

Boso, Nathaniel, Vicky Story, John Cadogan, Milena Micevski, and Selma Kadić-Maglajlić. 2013. Firm innovativeness and export performance: environmental, networking, and structural contingencies. Journal of International Marketing 21 (4): 62-87.

Brennan, Ross, Nektarios Tzempelikos, and Jonathan Wilson. 2014. Improving relevance in B2B research: Analysis and recommendations. Journal of Business \& Industrial Marketing 29 (7/8): 601-609.

Cayla, Julien, and Giana M. Eckhardt. 2007. Asian brands without borders: Regional opportunities and challenges. International Marketing Review 24 (4): 444-456.

Cayla, Julien, and Giana M. Eckhardt. 2008. Asian brands and the shaping of a transnational imagined community. Journal of Consumer Research 35: 216-230.

Cho, Jinwan, Eunmi Kim, and Insik Jeong. 2017. International orientation and cross-functional integration in new product development. Asian Business \& Management. doi:10.1057/s41291-0170024-4.

Choi, Thomas, and Daniel Krause. 2006. The supply base and its complexity: Implications for transaction costs, risks, responsiveness, and innovation. Journal of Operations Management 24 (5): 637-652.

Cooper, Robert G. 2000. New-product performance: What distinguishes the star products. Australian Journal of Management 25 (1): 17-45.

Daneels, Erwin, and Elko Kleinschmidt. 2001. Product innovativeness from the firm's perspective: Its dimensions and their relation with product selection and performance. Journal of Product Innovation Management 18 (6): 357-373.

Dawson, Leslie M. 1971. Marketing science in the age of Aquarius. Journal of Marketing 35 (3): 66-72.

Deshpandé, Rohit, and John U. Farley. 2004. Organizational culture, market orientation, innovativeness, and firm performance: An international research odyssey. International Journal of Research in Marketing 21: 3-22. 
Drucker, Peter F. 1954. The practice of management. New York: Harper \& Row.

Eisingerich, Andreas B., and Gaia Rubera. 2010. Drivers of brand commitment: A cross-national investigation. Journal of International Marketing 18 (2): 64-79.

Fan, Ying. 2002. Questioning guanxi: Definition, classification and implications. International Business Review 11 (5): 543-561.

Fang, Tony. 2006. Negotiation: The Chinese style. Journal of Business \& Industrial Marketing 21 (1): 50-60.

Faure, Guy Olivier, and Tony Fang. 2008. Changing Chinese values: Keeping up with paradoxes. International Business Review 17 (2): 194-207.

Garcia, Rosanna, and Roger Calantone. 2002. A critical look at technological innovation typology and innovativeness terminology: A literature review". Journal Product and Innovation Management 19 (2): $110-132$.

Goldsmith, Ronald E., François d'Hauteville, and Leisa R. Flynn. 1998. Theory and measurement of consumer innovativeness. European Journal of Marketing 32 (3/4): 340-353.

Gurhan-Canli, Zeynep, and Rajeev Batra. 2004. When corporate image affects product evaluations: The moderating role of perceived risk. Journal of Marketing Research 41 (2): 197-205.

Han, Jin K., Namwoon Kim, and Rajendra K. Srivastava. 1998. Market orientation and organizational performance: Is innovation the missing link? Journal of Marketing 62: 30-45.

Hanna, Richard, Andrew Rohm, and Victoria Crittenden. 2011. We're all connected: The power of the social media ecosystem. Business Horizons 54 (3): 265-273.

Henard, David H., and David M. Szymanski. 2001. Why some new products are more successful than others. Journal of Marketing Research 38 (3): 362-375.

Hennig-Thurau, Thorsten, Kevin P. Gwinner, Gianfranco Walsh, and Dwayne D. Gremler. 2004. Electronic word-of-mouth via consumer-opinion platforms: What motivates consumers to articulate themselves on the internet? Journal of Interactive Marketing 18 (1): 38-52.

Hirunyawipada, Tanawat, and Audhesh K. Paswan. 2006. Consumer innovativeness and perceived risk: Implications for high technology product adoption. Journal of Consumer Marketing 23 (4): 182-198.

Hobday, Mike. 1995. East Asian latecomer firms: Learning the technology of electronics. World Development 23: 1171-1193.

Hong, Gahye, and Eunmi Kim. 2017. Overcoming country-of-origin image constraints on hiring: The moderating role of CSR. Asian Business \& Management. doi:10.1057/s41291-017-0023-5.

Hubert, Marco, Arnd Florack, Rafael Gattringer, Ellen Enkel, and Peter Kenning. 2017. Flag up! Flagship products as important drivers of perceived brand innovativeness. Journal of Business Research 71: $154-163$.

Hult, G.Tomas, Robert F. Hurley, and Gary A. Knight. 2004. Innovativeness: Its antecedents and impact on business performance. Industrial Marketing Management 33: 429-438.

Hurley, Robert F., G. Tomas, and M. Hult. 1998. Innovation, market orientation, and organizational learning: An integration and empirical examination. Journal of Marketing 62: 42-54.

Hutchings, Kate, and David Weir. 2006. Guanxi and wasta: A comparison. Thunderbird International Business Review 48 (1): 141-156.

Hwang, Jinsoo, and Sunghyup Sean Hyun. 2016. Perceived firm innovativeness in Cruise travellers' experience and perceived luxury value: The moderating effect of advertising effectiveness. Asia Pacific Journal of Tourism Research 21 (1): 101-128.

Im, Subin, Barry L. Bayus, and Charlotte H. Mason. 2003. An empirical study of innate consumer innovativeness, personal characteristics, and new-product adoption behaviour. Journal of Academy of Marketing Science 31 (1): 61-73.

Im, Subin, Charlotte H. Mason, and Mark B. Houston. 2007. Does innate consumer innovativeness relate to new product/service adoption behavior? The intervening role of social learning via vicarious innovativeness. Journal of the Academy of Marketing Science 35 (1): 63-75.

Inemek, Aydin, and Paul Matthyssens. 2013. The impact of buyer-supplier relationships on supplier innovativeness: An empirical study in cross-border supply networks. Industrial Marketing Management 42: 580-594.

Jaworski, Bernard J. 2011. On managerial relevance. Journal of Marketing 75 (4): 211-224.

Jaya, Peruvemba S. 2001. Do we really 'know' and 'profess'? Decolonizing management knowledge. Organization 8 (2): 227-233.

Keller, Kevin Lane, and David Aaker. 1998. Corporate-level marketing: the impact of credibility on a company's brand extensions. Corporate Reputation Review 1: 356-378. 
Kirca, Ahmet, Satish Jayachandran, and William O. Bearden. 2005. Market orientation: A meta-analytic review and assessment of its antecedents and impact on performance. Journal of Marketing 69 (April): 24-41.

Kleijnen, Mirella, Ko de Ruyter, and Tor W. Andreassen. 2005. Image congruence and the adoption of service innovation. Journal of Service Research 7 (4): 343-359.

Kumar, V. 2014. Understanding cultural differences in innovation: A conceptual framework and future research directions. Journal of International Marketing 22 (3): 1-29.

Kunza, Werner, Bernd Schmitt, and Anton Meyer. 2011. How does perceived firm innovativeness affect the consumer? Journal of Business Research 64 (8): 816-822.

Lazonick, William, and Andrea Prencipe. 2005. Dynamic capabilities and sustained innovation: Strategic control and financial commitment at Rolls-Royce plc. Industrial and Corporate Change 14 (3): 501-542.

Lee, Yikuan, and Gina Colarelli O'Connor. 2003. The impact of communication strategy on launching new products: The moderating role of product innovativeness. Journal of Product Innovation Management 20: 4-21.

Martin, Felix, and Fu Tao-Peng. 2017. Morality matters? Consumer identification with celebrity endorsers in China. Asian Business \& Management. doi:10.1057/s41291-017-0022-6.

Mengüç, Bulent, and Seigyoung Auh. 2006. Creating a firm-level dynamic capability through capitalizing on market orientation and innovativeness. Journal of the Academy of Marketing Science 34 (Winter): 63-73.

Midgley, Gerald, John D. Nicholson, and Ross Brennan. 2017. Dealing with challenges to methodological pluralism: The paradigm problem, psychological resistance and cultural barriers. Industrial Marketing Management 62: 150-159.

Mota, J., and L.M. de Castro. 2004. A capabilities perspective on the evolution of firm boundaries: A comparative case example from Portuguese moulds industry. Journal of Management Studies 41: 295-316.

O'Cass, Aron, and Vida Siahtiri. 2013. In search of status through brands from Western and Asian origins: Examining the changing face of fashion clothing consumption in Chinese young adults. Journal of Retailing and Consumer Services 20 (2): 505-515.

Qian, Gongming, and Lee Li. 2003. Profitability of small- and medium-sized enterprises in high-tech industries: The case of the biotechnology industry. Strategic Management Journal 16 (June): 881-887.

Roehrich, Gilles. 2004. Consumer innovativeness: Concepts and measurements. Journal of Business Research 57 (6): 671-677.

Rogers, Everett M., and F. Floyd Shoemaker. 1971. Communication of innovations; A cross-cultural approach. New York: Free Press.

Rubera, Gaia, and Ahmet Kirca. 2012. Firm innovativeness and its performance outcomes: A metaanalytic review and theoretical integration. Journal of Marketing 76 (3): 130-147.

Sandvik, Izabela, and Kåre Sandvik. 2003. The impact of market orientation on product innovativeness and business performance. International Journal of Research in Marketing 20 (4): 355-376.

Sethi, Rajesh, Daniel C. Smith, and Whan Park. 2001. Cross-functional product development teams, creativity, and the innovativeness of new consumer products. Journal of Marketing Research 38 (1): 73-85.

Shukla, Paurav. 2011. Impact of interpersonal influences, brand origin and brand image on luxury purchase intentions: Measuring inter-functional interactions and a cross-national comparison. Journal of World Business 46: 242-252.

Shukla, Paurav, Jaywant Singh, and Madhumita Banerjee. 2015. They are not all same: Variations in Asian consumers' value perceptions of luxury brands. Marketing Letter 26 (3): 265-278.

Sponder, Marshall. 2012. Social media analytics: Effective tools for building, interpreting, and using metrics. London: McGraw Hill.

Srinivasan, Shuba, Koen Pauwels, Jorge Silva-Risso, and Dominique M. Hanssens. 2009. Product innovations, advertising, and stock returns. Journal of Marketing 73 (January): 24-43.

Steenkamp, Jan-Benedict E., and Steven M. Burgess. 2002. Optimum stimulation level and exploratory consumer behavior in an emerging consumer market. International Journal of Research in Marketing 19 (2): 131-150.

Steenkamp, Jan-Benedict E., Frenkel ter Hofstede, and Michel Wedel. 1999. Cross-national investigation into the individual and national cultural antecedents of consumer innovativeness. Journal of Marketing 63 (2): 55-69. 
Stremersch, Stefan, and Gerard J. Tellis. 2004. Understanding and managing international growth of new products. International Journal of Research in Marketing 21 (4): 421-438.

Tellis, Gerard J., Eden Yin, and Simon Bell. 2009a. Global consumer innovativeness: Cross-country differences and demographic commonalities. Journal of International Marketing 17 (2): 1-22.

Tellis, Gerard J., Jaideep C. Prabhu, and Rajesh K. Chandy. 2009b. Radical innovation across nations: the preeminence of corporate culture. Journal of Marketing 73 (January): 3-23.

Tellis, Gerard J., Stefan Stremersch, and Eden Yin. 2003. The international take-off of new products: The role of economics, culture, and country innovativeness. Marking Science 22 (2): 188-208.

Theoharakis, Vasilis, and Graham Hooley. 2008. Customer orientation and innovativeness: Differing roles in new and old Europe. International Journal of Research in Marketing 25: 69-79.

Tian, K.T., W.O. Bearden, and G.L. Hunter. 2001. "Consumers' need for uniqueness: Scale development and validation. Journal of Consumer Research 28: 50-66.

Tripsas, Mary. 1997. Unravelling the process of creative destruction: Complementary assets and incumbent survival in the typesetter industry. Strategic Management Journal 18: 119-142.

Truong, Yann. 2013. A cross-country study of consumer innovativeness and technological service innovation. Journal of Retailing and Consumer Services 20: 130-137.

Tse, Peter, and John C. Crotts. 2005. Antecedents of novelty-seeking: international visitors' propensity to experiment across Hong Kong's culinary traditions. Tourism Management 26 (6): 965-968.

Tuominen, Matti, Arto Rajala, and Kristian Möller. 2004. Market driving versus market driven: Divergent roles of market orientation in business relationships. Industrial Marketing Management 33: 207-217.

Walker, R.M. 2004. Innovation and Organisational Performance: Evidence and a Research Agenda. Advanced Institute of Management Research Paper No. 002. SSRN: https://ssrn.com/abstract= 1306909 or doi:10.2139/ssrn.1306909, accessed 25 August 2017.

Wang, Catherine L., and Pervaiz K. Ahmed. 2007. Dynamic capabilities: A review and research agenda. International Journal of Management Review 9 (1): 31-51.

Wang, Cheng Lu, and Henry F. Chung. 2013. The moderating role of managerial ties in market orientation and innovation: An Asian perspective. Journal of Business Research 66 (12): 2431-2437.

Watchravesringkan, K., Y. Ruoh-Nan, and J. Yurchisin. 2008. Cross-cultural invariance of consumers' price perception measures. International Journal of Retail and Distribution Management 36 (10): 759-779.

Wilson, Jonathan, and Ross Brennan. 2010. Doing business in China: is the importance of guanxi diminishing? European Business Review 22 (6): 652-665.

Wolfe, Richard. 1994. Organizational innovation: Review, critique, and suggested research directions. Journal of Management Studies 31 (3): 405-431.

Wu, Hsueh-Liang. 2008. When does internal governance make firms innovative? Journal of Business Research 61 (2): 141-153.

Yalcinkaya, Goksel. 2008. A culture-based approach to understanding the adoption and diffusion of new products across countries. International Marketing Review 25 (2): 202-214.

Yu, Yan A., Xiao-Ying Dong, Kathy Ning Shen, Mohamed Khalifa, and Jin-Xing Hao. 2013. Strategies, technologies, and organizational learning for developing organizational innovativeness in emerging economies. Journal of Business Research 66: 2507-2514.

Zhou, Kevin Zheng, Chi Kin Yim, and David K. Tse. 2005. The effects of strategic orientations on technology and market-based breakthrough innovations. Journal of Marketing 69 (April): 42-60.

Zinkhan, G.M. 2006. From the editor: Research traditions and patterns in marketing scholarship. Thousand Oaks: Sage.

Zolfagharian, Mohammad Ali, and Audhesh Paswan. 2009. Perceived service innovativeness, consumer trait innovativeness and patronage intention. Journal of Retailing and Consumer Services 16: $155-162$.

Ibrahim Abosag is an Associate Professor in International Marketing at SOAS, University of London. His research interests include cross-cultural B2B, brand relationships, online marketing, and consumer boycotting behaviour. Ibrahim has published in various academic journals including Industrial Marketing Management, Journal of Business Research, International Business Review, European Journal of Marketing, Journal of Marketing Management, Total Quality Management and Business Excellence, 
Journal of TQM, International Journal of Consumer Studies, Qualitative Market Research: An International Journal and others.

David Ross Brennan is Professor of Industrial Marketing at the University of Hertfordshire, England. His research interests include cross-cultural marketing, social marketing, business-to-business marketing, and business education. Ross has co-authored four books, including Marketing: An Introduction with Gary Armstrong, Philip Kotler and Michael Harker; and has published in a number of academic journals such as Industrial Marketing Management, European Journal of Marketing, Journal of Business Research, Journal of Marketing Management, Journal of Business \& Industrial Marketing, Journal of Macromarketing, and the Journal of Marketing Education. 